\section{ON THE TREATMENT OF ORCHITIS BY INCISION.}

To the Editor of THE IAANCET.

Sir,-You have given great prominence to the subject of the treatment of orchitis by incision, by discussing the question in a leader in last week's LAxcer, and I shall feel obliged if you will permit me to offer a few observations on this matter.

It will be in the recollection of many of your readers that, some six years ago, I drew attention to the treatment of orchitis by the plan of puncturing: the testis; a practice I had accidentally, as it were, stumbled upon, and which I had adopted with signal success at the time I published my paper in the pages of THE LANCer. Since this period I have carried out this practice in every suitable case which presented itself at the hospital, and in cases in private as well, and I suppose that I must have punctured the testis for acute orchitis in at least five hundred cases and although $I$ quite endorse your remark that in slight attacks of orchitis incision is useless, I am justified by ample experience in stating this mode of treatment in severe cases is not dangerous.

With the exception of two instances where some temporary inflammatory mischief ensued after puncturing the testis, I have not met with a single instance where bad results of any kind have occurred. I have not met with one case where-as might have been expected-any fistulous communication with, or protrusion of, the seminiferous tubules has occurred; nor have $I$ seen a single instance where a wasting of the organ itself has taken place after this treatment. When I first adopted this apparently heroic plan, and showed it to my pupils and friends, I was assailed with all sorts of dismal portents-of degenerated organs, and other ills; consequently I have been on the look out for such occurrences; and indeed I have met with two instances where the testicle had become destroyed after acute inflammation, but in these two cases the ordinary methods of treatment-namely, leeches and tartar emetic, usque ad nauseam, had been employed, but not incision.

M. Vidal de Cassis, who originated this practice-a fact unknown to me when I published my papen in THE LANCET -operated upon 400 cases at the time he wrote his work on "Venereal Diseases," and his experience is identical with my own-viz., speedy relief of most of the distressing symptoms of orchitis, and an absence of any injurious results to the organ from the puncture.

As illustrating the great relief which follows upon this plan of treatment, I may mention that patients have repeatedly come to me at the hospital to submit to the treatment a second time, having during a preceding attack of orchitis in the same or the other testis, so rapidly lost their acute sufferings by means of the incision through the tunica albuginea.

As to the destruction or wasting of the testicle being produced by a simple puncture into the body of the inflamed organ with a sharp, clean, narrow-bladed knife, I can neither believe nor understand it. It is the violence of the inflammatory process, as M.Vidal, and my friend Mr. Nunn, of the Middlesex Hospital, suggest, which does the mischief; and that violence is subdued by the treatment I advocate, and which I am sure, if properly tested, will supersede all other methods in ihis very painful disorder.

I remain, Sir, your obedient servant,

Wimpole-street, Feb. 22nd, 1870.

HENRY SMITH.

\section{THE FUNGUS-FOOT OF INDIA. To the Editor of THE LANCET.}

Sir,-As it is possible the first part of the report of the Pathological Society's proceedings, published in Tre LANCeT of December 11, 1869, may convey the impression that the fungous origin of the "roe-like" masses in the second and more common variety of mycetoma, or fungus-disease, was hastily assumed, I beg permission, through your columns, to observe that ordinary microscopic examination furnishes but part of the collected evidence, even in the hauds of an expert, and to suggest that an attempt be made by the gentlemen composing the Societr's conmittee to reproduce, by artificial cultiration of these "roe-like" masses, the fungus named by the Rev. Mr. Berkeley Chionyphe Carteir, as has been done in India, and also in England, with success.

Entertaining, as I do, the firm belief that the madura foot, of which Dr. Shortt's specimen was, it cannot be doubted, an excellent example, is as essentially the result of fungus orowth as other affected feet (and hands) I hare described, it is not unbecoming to refer to the Transactions of the Medical and Phrsical Society of Bombar, for the years 1860 (chieffy), 1861 and 1862 (appendices), for the grounds on which this conriction is based. At page 108 of the volume for 1860, it is intimated that the late Professor Quekett failed to detect vegetable characters in Dr. Ballingall's well-mounted specimens, which were kindly shown to me also. Indeed, the clue to the true nature (respecting which I see no surmise put forth in THE LANCET's brief report), of these curious roe-like particles. was derived from examination of other varieties of mycetoma, first described in the Bombay Society's Transactions.

Most fully do I subscribe to the desirability of further and special inquiry being made into the nature of this disease, prefaced, I may add, with attentive consideration of what has been already advanced; and with little hesitation do I predict that the vegetable parasite would then be admitted as the sole essential cause of madura foot, and other allied affections.

Much, doubtless, remains to be done in India, but English pathologists (like our scientific botanists) might now themselves give a helping-hand. To doubt is not to test. But to repeat, more fully if needed, what is alreads reported as done, or to open a new line of inquiry - this is what is now wanted for the more complete elucidation of the common form of the second variety of mycetoma, or the fungusdisease of India. Respecting all other forms with which I am acquainted, there is absolutely no ground for demur.

I am, Sir, your obedient servant,

H. Vandyke Carter, MI.D. Lond.

Satara, January, 1870. Surgeon to Her Mlajesty's Bombay Army.

\section{DR. C. J. B. WILLIAMS VERSUS THE DUKE AND DUCHESS OF SOMERSET.}

To the Editor of THE LANCET.

Sir,-My letter, which was published in your last number, was written ehiefly because I thought it due to the Duchess of Somerset to state that I received from her Grace no permission to perform the operation of tracheotomy for the late Earl St. Maur. I was, in fact, even not aware at the time that the Duchess, or any relative, was present; nor did I hear Di: Williams say anything to the lady whom I afterwards ascertained to be the Duchess, nor did I hear her say anything to Dr. Williams before the operation.

I was told, later, by Dr. Williams, that he used words similar to those which I quoted, and which, you will observe, I did not profess to quote exactly, but only gave their general effect.

I did not see Mr. H. Williams's letter before it was sent to you; but he called on me, and informed me verbally as to what he was going to say.

I am most happy to see that Dr. Williams is about to publish an account of this case, which will, doubtless, set right all the inaccuracies of Sir J. D. Coleridge's statement. That these inaccuracies-uncorrected as they were by the counsel on the other side-should have misled you is not surprising, nor did I mean to make it a matter of complaint; and $I$ regret that my letter should have produced any such impression.

I have thought it my duty to write to you, partly on the above point, and partly as to the duration of life after the operation, which I regard as an inportant feature in the case. I remain, Sir, your obedient servant, Clarges-street, Jiarch Sth, 1570 . T. Holires.

\section{UTERINE HEMIORRHAGE AFTER LABOUR.} To the Editor of ThE LAxceT.

Sir, - I was much impressed with Mr. Broke Gallmey's mode of arresting post-partum hæmorhage, as recorded by bim in gour issue of the Sth January. In sour number of the 15th, Dr. Rubert Barnes tries to throw cold water on 
the treatment. He says the bleeding may be arrested for a time by contraction of the uterus consequent upon the shock, but it will relax again, and the hæmorrhage return.

My object in troubling you with this communication is to point out that by very simple means this subsequent relaxation can be prevented. When the uterus is contracted by the shock, let the operator compress it firmly with his hands till a small bowl is brought to him, which, when placed over the uterus and firmly retained in position by means of a binder, most effectually prevents any relaxation of the uterus and recurrence of the hæmorrhage. In the cases in which $I$ have had recourse to this method, I semoved the bowl in from sixteen to twenty-four hours. The difficulty I have always found in cases of post-partum hæmorrhage has been to get the uterus to contract, not to keep it contracted; and should Mr. Gallwey's method be found to be even frequently successful, the best thanks of the profession are due to him for having made it known to them.-I am, Sir, your obedient servant,

J. J. Hardesty, L.R.C.P. \& S. E.

Lochee, Dundee, Jan. 27th, 1870

\section{NEWCASTLE-ON-TYNE. \\ (FROM OUR OWN CORRESPONDENT.)}

WrTH deep regret I write to acquaint you with the death of Mr. Stanley Peacock, who died this morning, after an illness of about fourteen days. Mr. Peacock, unfortunately, in making a post-mortem in a case of peritonitis, absorbed some matter through an abraded surface. Severe constitutional symptoms at once set in, followed by formation of abscess, and the usual concomitants of such an accident. Mr. Peacock only a few months since succeeded Dr. Bolton as house-surgeon to the Infirmary, but in that short time had made many friends, and had given much satisfaction by his ability and courteous activity. He was attended with great kindness by Drs. Charlton, Philipson, and Heath, and these gentlemen at an early period of his illness took a very gloomy view of his case. Mr. Peacock himself, too, considered his case hopeless. He was only in his twenty eighth year, and had held the office of house-surgeon for about eight months. He was educated at the City of London School, under Dr. Mortimer, and gained high honours there. The news of his untimely death will be received in Iondon, his native city, with great sorrow by a large circle of friends. Mr. Peacock was considered one of the best anatomists of his day. He carried off gold and silver medals at University College in his favourite pursuit, and he acted as demonstrator there for a considerable period. He came down to Newcastle with very high testimonials, including a special recommendation from Sir H. Thompson. There can be no doubt that, had bis life been spared, he would have occupied a high position in his profession. It might be mentioned here that Mr. Dodd, a student who assisted $\mathrm{Mr}$. Peacock in his unfortunate post-mortem, suffered severely too, but, fortunately, never was in great danger. This would go to show the malignant nature of the fluids in these cases, and the necessity of observing extreme caution in the conduct of examinations of this character.

Newcastle-on-Tyne, March 8th, 1870.

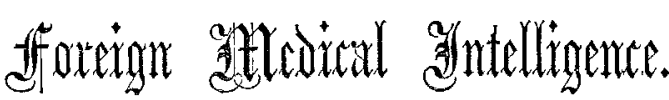

\section{(FROM OUR SPECIAL CORRESPONDENT.)}

Opening of a Dispensary for Diseases of Women in TurinSuccess of the Belgian Medical Federation-A curious giftForeign prizes open to medical men of all countries-Liberty of teaching in France-Banquet to an Italian doctor-Sanitary and meteorological condition of the Continent.

THE municipal authorities of Turin have decided on opening a Dispensary for the Diseases of Women, at the public expense. The new dispensary forms an anneze of the lying-in wards of Professor Tibone, who has informed the medical men of the town, by circular, that henceforth all poor females affected with uterine disease may be directed to his dispensary. It is needless to insist on the value of this measure, which is destined to alleviate the sufferings of so large a portion of the female population of Turin.

The Belgian Medical Federation, which may be compared in many points to the British Medical Association, has rapidly attained the greatest success. It is now in prosperous circumstances, and already numbers as many as thirty-four provincial societies, with a total of nine hundred members.

Signore Miraglia, the well-known Italian Professor, has just made a most curious gift to the Anatomical Museum of Naples. It consists of the skulls of ten criminals, a few of which had remained during more than sixty years stuck up on the walls of Castel Capuano, a monument of the barbarous ages. The professor has added to this oift an authentic history of the skulls, accompanied by various physiological and anatomical considerations on their appearance; and he purposes to adopt this as the subject-matter of a course of lectures which he will shortly deliver at Naples.

In my foreign chronicle in THE LANCET of the 5th ult. I gave you a complete list of the prizes of the Paris Academy of Medicine for the years 1870 and 1871. It was of the more importance to set this fully before the notice of your readers as the prizes of the Academy are open to the medical men of all countries. For the same reason, it is of interest to take note of the following prizes which have just been announced for competition by two other continental academies.

Italy.-The Riberi Prize. This is an important, prize, amounting to 20,000 lire, or $\$ 800$. It will be bestowed in 1871, by the Turin Academy of Medicine, on the author of the best work, printed or manuscript, published during the triennial period 1868 to 1870 , or on the author of a discovery made during the same lapse of time-the said work or discovery to be judged as having best contributed to the progress or benefit of the science of medicine. The works must be written in Italian, Latin, or French. Translations of other languages must be accompanied by the original. The worlss must be sent in to the Academy, free of all expense, on or before December 31st, 1870. Authors who desire to conceal their names rnust enclose them in a sealed envelope, according to the academical usage. The authors are invited to point out to the Academy such parts of their worles as they consider more particularly worthy of interest. The last Riberi Prize was awarded to a German author.

Belgium.-The Royal Academy of Belgium has set forth the following programme of prizes : - First question : "Write out the history of vitulary (?) fever; show the phy siological conditions in which it takes rise; point out the character, the pathognomonic symptoms, the course and treatment of the affection, as well as the lesions which are discovered after death." A medal of 500 francs. Memoir to be sent in on or before Jan. 1st, 1871. - Second question: "On the employment of disinfecting substances in certain industrial arts, in agriculture, and in domestic employment." A medal of 600 francs. Memoirs to be sent in on or before May 1st, 1871.- Prize for 1872 "Search out the causes of typhoid fever, sporadic or endemic. Show the prophylaxis and treatment of this disease." Furthermore, the Academy desires the competitors, in making out the causes of typhoid fever, to investionate the question whether the magnetic power of the earth exerts any influence on the genesis of epidemical typhoid ferer. A medal of 1000 francs. Memoirs to be sent in on or before March 1st, 1872.

France.-The Société Protectrice de l'Enfance has announced its annual prize, to be awarded in 1871. The prize will be a sum varying from 500 to 1000 francs, according to the value of the successful memoir. The subject chosen is the following:-" Investigate the causes of the excessive mortality of children during the first year of their existence, and the means of restricting it." Attention is called to the following points. The writers must, (1) Study in all its forms, and under all its aspects, the question of infanticide, such as it is defined by law-namely, the murder of a new-born child; (2) Deseribe the different cireumstances which may determine death in children-abandonment; the absence, insufficiency, or bad quality of food, whether natural or artificial; cold, filth, want of proper 